\title{
TREVISAN RESGATA TREVISAN EM PAI, PAI: o hibridismo no romance autobiográfico
}

\section{TREVISAN PORTRAITS TREVISAN IN PAI, PAI: hybridism in the autobiographical novel}

\section{TREVISAN RESCATA TREVISAN EN PAI, PAI: el hibridismo en la novela autobiográfica}

\author{
iD (9) Edcleberton de Andrade Modesto \\ Pontifícia Universidade Católica do Rio Grande do Sul (PUCRS), Porto Alegre, Rio Grande \\ do Sul, Brasil. \\ E-mail: edcleberton@gmail.com \\ iD Ricardo Barberena \\ Pontifícia Universidade Católica do Rio Grande do Sul (PUCRS), Porto Alegre, Rio Grande \\ do Sul, Brasil. \\ E-mail: ricardo.barberena@hotmail.com
}

\begin{abstract}
Resumo: O romance autobiográfico, por si só, é uma transgressão do que se compreende a respeito de ficção. As apropriações de espaços, pessoas e fatos reais inseridos no enredo criam narrativas-romances de si. Por sua vez, esse embate entre o ficcional e o real pressupõe o hibridismo e a fragmentação. Assim, ao analisar a obra Pai, pai (2017), de João Silvério Trevisan, a partir dos pressupostos teóricos de Samoyault (2008), Watt (2010) e Lejeune (2008), os resultados encontrados apontam para a indecidibilidade do gênero em questão e a legitimidade perante a sua forma livre, ou seja, sua estrutura fragmentada.
\end{abstract}

Palavras-chave: Hibridismo. João Silvério Trevisan. Pai, pai. Romance autobiográfico.

Abstract: The autobiographical novel on its own terms is a sort of transgression of what one understands as fiction. By drawing upon 
places, people and even true events inserted into literary productions, the autobiographical novel ends up creating narratives and novels of the self. Consequently, the blur between reality and fiction brings to the fore not only hybridism but also fragmentation. By analyzing João Silvério Trevisan's Pai, pai (2017) taking as theoretical framework Samoyault's (2008), Watt's (2010) and Lejeune's (2008) contributions, the findings of this research highlight how difficult it is to label that genre as well as the legitimacy of its free form, in other words, its fragmented feature.

Keywords: Hybridism. João Silvério Trevisan. Pai, pai. Autobiographical novel.

Resumen: La novela autobiográfica, por sí sola, es una transgresión de lo que se comprende respecto a la ficción. Las apropiaciones de espacios, personas y hechos reales introducidos en la trama producen narrativas de uno mismo. A su vez, ese embate entre la ficción y la realidad presupone el hibridismo y la fragmentación. Así, al analizar la obra Pai, pai (2017), de João Silvério Trevisan, a partir de las presuposiciones teóricas de Samoyault (2008), Watt (2010) y Lejeune (2008), los resultados encontrados apuntan para la indefinición de este género y la legitimidad frente a su forma libre, o sea, su estructura fragmentada.

Palabras clave: Hibridismo. João Silvério Trevisan. Pai, pai. Novela autobiográfica.

Submetido em 12 de março de 2021.

Aceito em 02 de julho de 2021.

Publicado em 03 de novembro de 2021. 


\section{Considerações iniciais}

"Pai, pai, por que me abandonaste?" (Salmo 22,1)

O fragmento do salmo bíblico acima condiz com as últimas palavras de Jesus na cruz, seu lamento representa a solidão absoluta e, ao mesmo tempo, a experiência da presença de um pai que se dá a partir do sentimento da ausência. No entanto, somente ao narrar essa passagem, ápice de uma vida marcada por dolorosas provações, é que se torna presumível que o seu locutor - Jesus parece protestar e implorar a misericórdia de Deus. Ao fazer alusão acima aos dois indivíduos, os arquétipos de um pai omisso e de um filho abandonado parecem se repetir na história. Segundo Flora Süssekind (1984), o orgulho de um pai a um filho parecido é dizer: tal pai, tal filho. O reconhecimento se dá na semelhança; assim, maior será a ênfase orgulhosa no tal que se repete. Do filho é exigido a duplicação de qualquer traço registrado na família, o qual se espera a semelhança, a repetição e a continuidade. Dessa forma, ao olhar para um filho, o que se espera é que este seja taIhado à imagem e semelhança do pai. É a esta última alusão que se aplaude ao dizer "tal pai, tal filho"; é a garantia de reconhecimento de um no outro. No entanto, quando as diferenças são demasiadas, quebra-se essa possibilidade de reconhecimento mútuo; fratura-se, desse modo, a herança paterna numa inquietante estranheza. Logo, os elementos da máxima se invertem e ela se abre em dúvida: tal filho, qual pai?

A similaridade em alguns aspectos e as diferenças em outros tantos fazem o leitor perspicaz se debruçar sobre a literatura brasileira contemporânea ao encontrar João e José, personagens principais do romance Pai, pai (2017), de João Silvério Trevisan. No texto, além de ser o autor, João também é o narrador que relata, através de fragmentos, as reminiscências de uma relação conturbada que teve durante toda a vida com seu pai, bem como a opressão causada pela brutalidade e pelas dores de uma convivência dura e 
sofrida, por vezes, insuportável. Assim, no intuito de compreender a ausência de José, o qual exerce sua função paterna conforme os ditames da brutalidade, rudeza e, geralmente, da violência, João revira seu passado pouco afetivo e acolhedor em busca de uma reconciliação na relação com seu pai.

A partir disso, ao observar algumas caraterísticas das narrativas contemporâneas, é perceptível averiguar aspectos que já não passam desapercebidos sob um olhar analítico e que, portanto, se configuram como uma reinvenção da narrativa. Isso posto, este trabalho tem por objetivo principal apresentar uma análise crítica a respeito da obra Pai, pai (2017), de João Silvério Trevisan, no intuito de permitir um espaço de questionamentos, reflexões e considerações que o romance autobiográfico apresenta, bem como analisar as principais características deste tipo de narrativa e do narrador enquanto personagem de sua própria história.

Desse modo, partindo do pressuposto da inexistência de investigações sobre o corpus citado através do viés escolhido, torna-se oportuno evidenciar a relevância de uma pesquisa que discuta as hipóteses a seguir: estaria o romance autobiográfico transgredindo os limites daquilo que se entende por ficção? O narrador autobiográfico exerce uma autoridade artificial sobre a narrativa capaz até mesmo de adicionar consciência como forma de inferir confiabilidade ao que fora narrado? Poderia se afirmar o hibridismo e a fragmentação como recursos que revelam o conflito entre o ficcional e o real utilizado pelo autor do romance acima?

Ao colocar em pauta tais questionamentos, faz-se necessário compreender o contexto nebuloso que perdura, até hoje, acerca da escrita de si, a qual alguns tipos de romances fazem parte. Estes assumem o rótulo de não serem considerados um tratado puramente ficcional, e, sim, um "texto em que o autor parece expressar sua vida ou seus sentimentos, quaisquer que sejam a forma do texto e o contrato proposto por ele" (LEJEUNE, 2008, p. 53, grifo nosso). Dessa forma, o romance a que todos estão habituados, no qual não existe compromisso algum com a precisão da realidade, exceto apenas quando se assevera a soberania da arte mimética e da 
verossimilhança, começa a dar "[...] sinais de inquietação, afasta e indaga, inicia tímidos ensaios de apropriação, e entra em nosso século com evidentes manifestações de inquietação formal, de ansiedade [...]" (CORTÁZAR, 1974, p. 70). Em outras palavras, "[...] o romance supera todo o concebível em matéria de parasitismo, simbiose, roubo com agressão e imposição de sua personalidade" (CORTÁZAR, 1974, p. 68).

Considerando os postulados anteriormente apresentados, faz-se importante trazer a lume essa narrativa sob a perspectiva investigativa, no intuito de que se possa, assim, compreender a respeito de como o hibridismo e a fragmentação se incorporam no romance autobiográfico brasileiro contemporâneo, bem como explorar a obra de João Silvério Trevisan, ainda pouco analisada por estudantes e profissionais da área de Letras e Artes.

\section{Hibridismo e fragmentação em Pai, pai}

De acordo com os estudos de Philippe Lejeune (2008), é sabido que o gênero autobiográfico cria um pacto com seu leitor na presunção de que todo ele seja um quadro factual. No entanto, depreende-se que este mesmo pacto se caracteriza por um conjunto de escolhas de exposição e forma. Nesse sentido, tal argumentação se aproxima das ideias de Cortázar (1974) ao ressaltar a forma poliédrica e amorfa a que o romance contemporâneo está destinado, por isso sua capacidade de agregar e incorporar ficções de memória relatadas em forma de depoimento, as quais se misturam às dores da experiência vivida a ponto de se confundirem com a ficção.

Dentro dessa perspectiva, o romance de Trevisan representa a tríade perfeita, pois, nele, João é autor, narrador e personagem de sua própria história, "como se, através da alegoria mais ou menos transparente da ficção, fosse sempre afinal a voz de uma só e mesma pessoa, o autor, a revelar a sua confidência" (BARTHES, 2012, p. 58, grifo do autor). Ao conjunto dessa tríade, estabelece- 
TREVISAN RESGATA TREVISAN EM PAI, PAI: o hibridismo no romance autobiográfico Edcleberton de Modesto • Ricardo Barberena

-se o chamado pacto autobiográfico', que ao contrário do que se pensa, não diz respeito a um acordo, contrato entre quem escreve e quem lê, mas sim à autenticidade da assinatura, que paira entre o particular e o público, entre a expressão de uma subjetividade e o prosaísmo.

Radicalizando ainda mais a questão acima, é possível inferir a ideia de uma oscilação entre os limites do real e do ficcional. Desse modo, o paradoxo entre esses dois polos indica a existência de um discurso autobiográfico com características de uma performance ficcional. Isso posto, no entanto, é necessário se levar em consideração que, apesar desse aprofundamento no ser, a reprodução de modelos ficcionais autobiográficos é envolvida por uma fina camada de fingimento, pois é esse o único caminho disponível para o romancista descrever sua realidade, uma vez que esta se trata de uma instância inefável. Em outras palavras, ainda que exista uma ligação estrita entre o eu e a ficção ou mesmo entre realidade e ficção, o elo entre o eu e a realidade acontece de forma indireta.

É curioso perceber que, ao mesmo tempo em que Barthes (2012) anunciava a morte do autor, os romancistas privilegiavam, em suas obras, traços autobiográficos. Desse modo, torna-se evidente a introdução de uma narrativa com exploração psicológica e traços de monólogos interiores, ou seja, uma espécie de desagregação da forma do romance do século XIX e início do XX. Tudo isso sem as características de uma literatura de mensagem explícita, pois o romancista do século XXI, de modo geral, encontra impedimentos na maneira com que formula respostas, devendo evitar, com isso, as simples. O máximo que ele faz é buscar, na ausência de uma verdade absoluta, relatos pessoais ou alheios que Ihe sirvam de parâmetros para compreender, mesmo parcialmente, o que acontece. Em Pai, pai, uma vez que estes pequenos eventos narrados não têm lugar no jornalismo, na ensaística ou mesmo na historiografia, é no romance, portanto, que João encontra uma forma de abrigo afetivo de sua história, assim ele busca: "descobrir

1 Segundo Lejeune (2008), o pacto autobiográfico é uma afirmação de identidade que remete, em última instância, ao nome do autor, escrito na capa do livro, e suas formas são diversas. Para o teórico, a autobiografia é, principalmente, uma narrativa com perspectiva retrospectiva e cujo assunto tratado é a vida individual. 
o obscuro começo da minha trajetória: como, por que e de onde surgiu esse espermatozoide tão estranho, tão improvável. Única certeza: eu sou o que sobrou de um gozo tão espasmódico quanto um esgar agônico" (TREVISAN, 2017, p. 7).

Essa autorreferencialidade que aparece em toda a obra aos poucos vai revelando a trágica vida de violência do contexto absurdamente machista que o narrador-personagem vivencia desde sua infância e, talvez, seja por isso mesmo que a narrativa permite uma abordagem sobre sua identidade em ascensão e de sua sexualidade latente, a qual ele precisou esconder diversas vezes de seu pai por sofrer opressão, ou por conta do conservadorismo que existia quando ele decidiu entrar para o seminário.

O romance autobiográfico como gênero literário adquire, na contemporaneidade, uma espécie de hibridismo, misturando dados históricos e ficção, ou mesmo expondo condições externas da produção do texto ficcional como legitimação de si mesmo. Assim, ao ultrapassar esses limites, essa injunção requer a urgência de uma revisão de paradigmas estéticos ao estabelecer a apropriação de novas formas de narrar, dando origem à cristalização de novos modelos autobiográficos. Uma vez que o pacto da autobiografia representa tudo aquilo que faz referência ao real do autor, tem-se, em contraposição, a etiqueta do título romance como sinônimo de ficção. Desse modo, "o romance é ação; e além disso, é compromisso, transação, aliança de elementos díspares que permitam a submissão de um mundo igualmente transacional, heterogêneo e ativo" (CORTÁZAR, 1974, p. 71).

Assim, conforme explicitado anteriormente, esses eixos de significações estão ligados, mas isso não quer dizer que eles são necessariamente correspondentes fieis. A tentativa de um grau zero do depoimento permite a autenticidade e profundidade do experienciado, no entanto, o prazer da narrativa bem conduzida cria, em última instância, uma ambiguidade. Portanto, por mais que a história pressuponha a realidade, existe algo de ficcional. A ordenação dos pormenores salientados ou omitidos, a ênfase dada a determinados fatos ou a perspectiva pelo qual eles são vistos e 
expostos dão ao enredo que se pretende verídico um know-how ficcional. Dessa forma, entende-se que a construção da instância narrativa se dá na articulação autodiegética.

Se por um lado o narrador e o autor são a mesma personagem, por outro lado aquele está distanciado no tempo, ele fala de sua vida retrospectivamente. Isto Ihe confere um maior saber, uma visão mais ampla, uma profundidade interna e externa. Isto certamente Ihe permite um flash-back no qual se fundamenta, mas também antecipações certas (REUTER, 2004, p. 77).

Corroborando com o pressuposto citado, é possível inferir que o personagem-narrador se remete ao sujeito da enunciação e ao sujeito do enunciado, pois ao narrar a história, a instância narrativa, é o autor o referente textual que se encontra fora do texto conferindo a si, ao mesmo tempo, distanciamento e aproximação dos fatos ocorridos. Logo, variando ora como uma construção de uma imagem de si, ora como um desdobramento de sua polifonia enquanto sujeito, essa divisão de eus subentende um eu-reflexivo, ou seja, o narrador-autor e um eu da memória.

Dessa forma, ao se ler uma obra literária autobiográfica, o leitor confia na palavra do seu autor, mesmo quando elas parecem trazer o benefício da dúvida quanto à sua existência de fato ou não. Assim:

Um relato de vida isolado, se for suficientemente desenvolvido, se a voz e a perspectiva do modelo forem transcritas de maneira sugestiva, se permitir imaginar concretamente as situações e mentalidades, se enfatizar o interesse dramático que cada um tem pela própria vida, acaba provocando no leitor um efeito imaginário e afetivo de identificação (LEJEUNE, 2008, p. 183).

À medida que essa correlação entre vida biografada e sua escrita tem as bases confirmadas, o leitor tenderá por se interessar pelo relato com maior grau de veracidade, o que supostamen- 
te pode ser obtido quando o narrador-autor opta pela descrição minuciosa dos eventos, não se deixando recair nos labirintos da memória. O que existe, portanto, são níveis de gradação, ou também os chamados "graus de clareza", variando do nítido ao vago, ou até o impreciso. Lejeune (2008) admite a necessidade de relativizar a posição categórica e a existência de ambiguidades e de graus no espaço autobiográfico. A revisão do passado introduz o pacto fatalmente ligado à identidade, território no qual as categorias de verdade, de realidade e de ficção não podem ser nitidamente demarcadas. O desenrolar da autobiografia, pela sua própria natureza, implica uma predominância da voz do narrador, constantemente presente, no sentido de que ele escolhe e ordena as lembranças.

No entanto, é imperioso ressaltar que

as lembranças são histórias que contamos a nós mesmos, nas quais se misturam, sabemos bem isso hoje, falsas lembranças, lembranças encobridoras, lembranças truncadas ou remanejadas segundo as necessidades da causa. Toda autobiografia, qualquer que seja sua "sinceridade", seu desejo de "veracidade", comporta sua parte de ficção (DOUBROVSKY, 2014, p. 121).

Com efeito, o teórico acima equaliza as diferenças estéticas entre romance e autobiografia, na premissa de que toda narrativa de si é uma modelagem, ou seja, faz parte de uma roteirização romanesca da própria vida. Em consonância com esses pressupostos, mas dentro de uma outra análise temporal, pode-se considerar o argumento que afirma que há "[...] uma nova tendência na ficção: sua total subordinação do enredo ao modelo da memória autobiográfica afirma a primazia da experiência individual no romance [...]" (WATT, 2010, p. 16).

Ao suscitar o efeito esperado, na obra de Trevisan, por outro lado, pode-se perceber o esforço em desafiar e transgredir traços típicos do gênero ao lançar-se, com isso, sobre o inédito processo de inserção de novas propostas, o que confere, por sua vez, tom 
confessional a um caráter analítico-psíquico, como se durante o próprio processo de escrita houvesse uma elaboração como parte da aceitação do passado de João. Assim, ele diz que: "Sempre que procuro o jovem José, aparece o jovem João, numa trama enredada por falhas, nós e emendas. Pedi ajuda à minha irmã, com quem coletei as vagas lembranças, às vezes complementadas por aproximações viáveis" (TREVISAN, 2017, p. 14). É possível averiguar que a identidade explícita do autor com o nome do narrador-personagem ressalta a maestria com as palavras ao fazer uma reflexão não apenas sobre um passado de lembranças reviradas e feridas abertas. O tom metaficcional, dessa forma, permite mergulhos inescapáveis na vida de João, bem como retornos imediatos ao tempo presente da escrita, revelando uma dor silenciada por anos de sofrimento.

À primeira vista, também é perceptível que, ao solicitar ajuda para sua irmã, ele se utiliza de uma fonte exterior a si próprio como forma de conferir veracidade à narrativa e de preenchimento dos espaços vazios que existem em sua memória, uma vez que ele admite o desconhecimento total de todos os fatos. Tem-se, portanto, um enredo entremeado por diálogos entre seus entes mais próximos. Isso acontece devido ao fato de sua idade avançada, explicitamente no momento em que, finalmente, decide externar toda sua vida, assim: "Já perto dos setenta anos, enquanto me tratava de uma depressão reincidente, comecei inopinadamente a escrever sobre esse homem chamado José, que me marcou com o ferro em brasa do seu sobrenome. Não me perguntei por que escrevia. Apenas decidi ir adiante" (TREVISAN, 2017, p. 8).

Por outro lado, numa espécie de catarsis, durante sua infância, a "eclosão da consciência" (TREVISAN, 2017, p. 7) permite em João a compreensão de sua "infância abandonada e à sua ferida incurável" (TREVISAN, 2017, p. 13), por isso, sua própria escrita se torna um "inventário de fantasmagorias" (TREVISAN, 2017, p. 13), pois ele chega "à velhice ainda preso a essa força que pode ser paralisante, mas também mobilizadora, até o ponto de me conduzir 
TREVISAN RESGATA TREVISAN EM PAI, PAl: o hibridismo no romance autobiográfico Edcleberton de Modesto • Ricardo Barberena

como uma marionete da dor, talvez até mesmo da desesperança" (TREVISAN, 2017, p. 13).

Enquanto filho, precisou aprender a lidar com o medo, o ódio e a indiferença paterna que ecoava em gestos e atitudes de José Trevisan. Essas marcas indeléveis apenas servem para comprovar, conforme o argumento do crítico sobre um outro romance autobiográfico: "[...] que a personagem deve ser vista como uma pessoa particular, e não como um tipo" (WATT, 2010, p. 21). Assim, retornando a Pai, pai, João adentra para além da superfície da ação, de forma a alcançar uma visão convincente do que se passava na sua mente e em seu coração. No entanto, mesmo assim ressalva já de início que "[...] há um grande risco de que eu esteja sendo injusto" (TREVISAN, 2017, p. 7). Esse posicionamento duvidoso parece destoar do estabelecimento de critérios que se entende por uma autobiografia, uma vez que a exatidão do relato traz ao leitor uma confiabilidade no fato, ao contrário do enunciado inexato que põe o leitor em dúvida quanto ao que fora narrado. Ao posicionar-se dessa forma, convém mencionar aquilo que Brian Richardson ${ }^{2}$ menciona a respeito da confiabilidade da narrativa na ficção contemporânea, cuja transgressão reside em seu caráter equívoco e especulativo.

\begin{abstract}
Eu me identifico com uma realidade que nunca existiu mas que é absolutamente minha e totalmente real, envolta numa aura dourada que só eu conheço. Minhas lembranças, eu as considero meus pequenos milagres de poesia. São fruto da infância que tive e de meus sonhos de garoto que voltam agora. Essas lembranças me tornam alguém bem mais feliz do que fui. Eu as ganhei de presente de mim mesmo (TREVISAN, 2017, p. 66).
\end{abstract}

Como pode ser observado no trecho acima, ao fazer comentários explícitos como esse, o narrador-personagem atesta para a particularidade de suas memórias, bem como reafirma sua capacidade em enxergar a beleza poética circunscrita em sua vida,

2 Brian Richardson (2006) nomeia aspectos transgressores na narrativa, dentre os quais está o narrador contraditório, o qual nega ou subverte a ordem no ato de narrar, gerando uma desconfiança por parte do leitor quanto à veracidade dos fatos. 
apesar do passado sofrido. Essa alta consciência dentro da narrativa corrobora para o resultado "[...] em boa parte dos duzentos e oitenta (ou mais) anos de análise/terapia que fiz [...]" (TREVISAN, 2017, p. 13). Levando este importante aspecto em consideração, torna-se possível explicar os processos criativos que aparecem ao longo do romance. $\mathrm{O}$ tom analítico-ensaísta presente em diversas passagens revela características metaliterárias de uma narrativa que avança sobre os limites ficcionais, dissertando, criticando ou mesmo opinando. Tudo isso somado ao vasto conhecimento de João adquirido através da literatura, a qual chegou através de sua mãe, Maria, bem como "foi também sob a égide da minha mãe que pude escapar para o seminário, longe do meu pai" (TREVISAN, 2017, p. 37). Ainda na mesma página, o narrador afirma que foi graças a esse fato que abriu "[...] espaço para desdobrar os meandros da minha homossexualidade ainda em conflito" (TREVISAN, 2017, p. 37).

Desse modo, além de uma narrativa despreocupada com os ditames padrões, João é a personificação de uma identidade transgressora. Neste momento, convém observar também o contraponto existente entre a figura materna e a paterna, uma vez que, enquanto a primeira é sempre apresentada como uma fonte de inspiração e representava a amabilidade, o afago, a segunda, por sua vez, demonstra o avesso da situação. Isso posto, pode-se afirmar que a fragmentação das lembranças de João marca rupturas profundas e deslocamentos de tendências literárias e de estilo, permitindo a reconfiguração e inovação de formas ultrapassadas. Assim, posicionadas de forma cronológica, a obra mostra o processo de declínio da vida de José, com a falência do bar e da padaria através de sua administração fracassada, levando-o ao alcoolismo. Por outro lado, também narra a construção de João em meio às suas dificuldades quando entra para o seminário em São Carlos, e de sua vida adulta em São Paulo e outras cidades do mundo, nas quais precisou de abrigo para fugir da ditatura que o ameaçava por ser escritor, homossexual e militante. 
TREVISAN RESGATA TREVISAN EM PAI, PAl: o hibridismo no romance autobiográfico Edcleberton de Modesto • Ricardo Barberena

A inovação, elemento central em Pai, pai (2017), supera as fronteiras e não se limita em definições fechadas do gênero em questão, inserindo ao documental elementos como a intertextualidade, a exemplo do capítulo "Aventureira' e outras canções", o qual faz menção às músicas e canções em que João se refugiava emocionalmente ao ouvir Miguel Acevez Mejía ou a $6^{a}$ Sinfonia de Tchaikóvski, bem como quando ele se utiliza do próprio texto para referenciar outras obras de sua autoria, exemplo de Ana em Veneza ${ }^{3}$, romance dedicado à sua mãe, ou seja, o narrador ${ }^{4}$ de Pai, pai (2017) insere personagens que transitam de um nível do texto a outro de forma impossível, a não ser através da ficção.

Além disso, na obra também é possível encontrar metalepses 5 , como nos capítulos "O eu claudicante", "Rastros por escrito (1)" e "Rastros por escrito (2)", os quais se caracterizam pela intrusão de um narrador-personagem metadiegético na narrativa original. Nesse caso, "a metalepse é entendida como uma transgressão de campos de ação reservados a entidades de mundo separados: personagens, narradores e espaços ficcionais, por um lado; autores empíricos, leitores e espaços reais, por outro" (GENETTE, 2017, p. 259). No entanto, é possível inferir, mais especificamente, que a metalepse presente nos dois capítulos diz respeito a personagens/ pessoas, narrador e autor iguais, criando um jogo permanente com a identidade do autor real e do seu narrador. A superposição de temporalidades e espacialidades indica características do hibridismo, que faz uso do literário para inserir o dado histórico real no intuito de desestabilizar o estatuto ficcional da narrativa.

Dessa maneira, ao pensar o conceito de hibridismo como um efeito de conexão entre dois mundos, o real e o ficcional, é necessário averiguar as semelhanças que existem entre eles, e compreender a heterogeneidade como um processo de diferença de textura entre o mundo e o texto, possibilitando ao autor recorrer

\footnotetext{
3 Romance escrito em 1994 por João Silvério Trevisan, que apresenta, a partir de seu título, uma de suas protagonistas e sua viagem à terra de Dante. Nessa trajetória na cidade de Veneza, entrecruzam-se os três personagens: Alberto Nepomuceno, personagem baseado no músico e compositor cearense homônimo, que vai à Europa para estudar piano; Julia Mann, referência à mãe do escritor alemão Thomas Mann; e Ana, a escrava que acompanhara a família em sua ida à Alemanha.

4 Brian Richardson (2006) denomina como narrador "des-enquadrado".

5 "O conceito de metalepse decorre do sentido etimológico do termo em causa: significando transposição, a metalepse pode ser definida, numa acepção primordial, como um movimento em que se opera a passagem de elementos de um nível narrativo para outro" (GENETTE, 2017, p. 258, grifo do autor).
} 
TREVISAN RESGATA TREVISAN EM PAI, PAI: o hibridismo no romance autobiográfico Edcleberton de Modesto • Ricardo Barberena

ao recurso da intertextualidade como meio essencial para construir e unir esses dois universos. Dessa forma:

\begin{abstract}
A intertextualidade faz assim aparecer uma primeira hibridez, que é também sua caracterização elementar, justapondo várias falas, vários contextos e várias vozes. Mas a hibridez do texto intertextual pode ser lida em outro nível, na heterogeneidade dos materiais que o constituem, podendo remeter a diferentes discursos. Assim se interpenetram às vezes discurso literário e discurso referencial, nas obras que valorizam a hibridez em detrimento da unidade, que reciclam os objetos do mundo, deixando aparecer o gesto da colagem, a operação de montagem (SAMOYAULT, 2008, p. 103-104).
\end{abstract}

Ao comprometer a solidez da forma de suas convenções, em Pai, pai (2017), Trevisan propõe uma ruptura na forma esclerosada do romance autobiográfico de outrora, elevando-o a ultrapassar os limites da ficção através de uma colagem de pequenos fragmentos da vida real reproduzidos diretamente em seu romance. Um exemplo desse tipo de efeito encontra-se em "Choro infantil e outras perdas", capítulo que mistura o ficcional ao seguinte fato real expressado:

Ainda adolescente, às vezes eu convidava mamãe para compartilhar minhas descobertas. Sabia quanto devia à sua figura. Lembro de tê-la levado, certa vez, ao Theatro Municipal de São Paulo, que eu costumava frequentar nos concertos matinais gratuitos dos domingos. Fomos ver Cacilda Becker em A dama das Camélias.

\title{
[...]
}

Curiosamente, a situação emulava a morte da própria Cacilda Becker. A atriz que vislumbrávamos no teatro tivera um derrame durante uma peça e, após passar mais de um mês em coma, morreu aos quarenta e oito anos. Minha mãe tinha cinquenta quando saiu de cena (TREVISAN, 2017, p. 42-43, grifo do autor). ${ }^{6}$

6 Detalhes do fato em questão está disponível em: https://www1.folha.uol.com.br/banco-de-dados/2019/06/1969-silencio-desceu-sobre-cacilda-que-foi-comparada-a-chaplin-e-desafiou-ditadura.shtml. Acesso em: 01 nov. 2020. 
Nesse sentindo, a obra se torna um arranjo interessante e desconcertante de gêneros literários, ao articular fragmentos de acontecimentos da realidade pertencentes ao vivido pelo narrador-personagem, geralmente situações essas que tiveram uma ligação afetiva e/ou emocional, como o exemplo acima, em que a lembrança do fato ocorrido se deu, principalmente, por coincidir com a perda de sua mãe. No entanto, ao recorrer à utilização desse mecanismo, a ideia central para entender a trama de João Silvério Trevisan é constatar a existência real do romancista e das personagens/pessoas que o rodeiam, sobretudo, mesmo aqueles mencionados como Cacilda Becker, em que peripécias ficcionais e reais se entrelaçam livremente. É necessário, assim, ressaltar também o movimento reverso que de modo amplo aparece nos romances autobiográficos, ou seja, "o abandono à hibridez é, em primeiro lugar, uma maneira de atenuar as fronteiras entre realidade e ficção, mesmo que seja só no desnudamento do procedimento de colagem" (SAMOYAULT, 2008, p. 104). Ao permitir esse movimento que vai do ficcional ao real e do real ao ficcional, o autor transita entre a imaginação e a realidade.

Em Pai, pai (2017), os fragmentos colados podem ser identificados claramente como advindos de um "real" externo, como quando se vê o narrador-personagem citar o filme $A$ cruz da minha vida (1952) 7, o qual "bastou para reviver meu trauma e me deixar vivamente assustado com a violência alcoólatra [...]" (TREVISAN, 2017, p. 49). A partir desse ponto, o capítulo ganha os contornos nítidos de uma sinopse fílmica e, fazendo uso da metalinguagem, por último, assume um tom reflexivo ao possibilitar a João fazer um comparativo do enredo do filme com a sua própria vida ao se questionar: "por que alguém escreveria uma peça que dói tanto? Por que um diretor decide adaptá-la ao cinema? [...] Perguntas assim eu tenho feito sobre várias das minhas obras - sem resposta clara. E refaço agora, insistentemente, ao escrever este livro" (TREVISAN, 2017, p. 49).

7 Intitulado originalmente por Come Back, Little Sheba, é um filme norte-americano dirigido por Daniel Mann e roteiro de Ketti Frings. 
Logo, a característica metaficcional que compõe a obra inclui nela mesma comentários sobre a própria narrativa, a exemplo: "[...] a minha literatura, desenvolvida na contramão de tudo aquilo que a minha família paterna desdenhava" (TREVISAN, 2017, p. 53). Essa participação consciente do narrador dentro do enredo revela um conhecimento antinatural para a perspectiva do mundo representado, imprimindo na narrativa uma visão soberana e autoral. No entanto, evidencia o centro do pensamento de onde irradia toda a sensibilidade responsável pelo desvelar dramático da vida do narrador-personagem, assim, quanto mais ele intervém, mais de seu íntimo é contado, ao passo que quanto menos interrompe, mais é mostrado.

Dessa forma, o leitor acessa "um episódio da minha infância que jamais comentei nem com pessoas mais próximas. Talvez por vergonha, ou para não provocar desnecessário constrangimento" (TREVISAN, 2017, p. 61). Logo, João vai revelando situações de sua infância, inclusive de abusos silenciados pela conivência de um desejo maior por um gesto de carinho, mesmo que fosse de Emílio, freguês de seu pai e casado, "Mais de uma vez ele me bolinou por detrás. Ficava sentado, e eu em pé, ao lado de sua cadeira. Nunca houve tentativa de estrupo ou algo assim. Era simplesmente bolinação silenciosa" (TREVISAN, 2017, p. 61). No entanto, é somente depois de anos que a compreensão do que aquilo representou se deu para ele, "[...] digamos que se trata de uma situação abusiva [...]" (TREVISAN, 2017, p. 62). Mesmo na sua infância o desejo e atração por homens já mostrava indícios de sua orientação sexual, a qual seria mais um agravante na relação com seu pai, uma vez que ele representava a face opressora.

Hoje me pergunto se tal encantamento não tinha a ver com o mistério compartilhado, que refletia o drama do meu segredo pessoal. Resguardar tão intensamente o amor proibido pelos homens me identificava com o mocinho mascarado - na medida exata do que eu sentia. Sem me dar conta, eu vivia num turbilhão em devir, ante a possibilidade de ser eu e um outro Eu Mesmo (TREVISAN, 2017, p. 62). 
Igualmente notável, o efeito da estratégia narrativa produzida acima evidencia uma projeção de consciência isolada responsável por uma inexplicável voz autônoma que surge de dentro do narrador já existente, revelando a nudez do próprio pensamento sobre determinada situação, como uma espécie de autoconhecimento. Isso pode ser observado através da mudança do tempo verbal que destoa da sequência narrativa a que o narrador vinha tecendo ao utilizar-se do verbo no presente: "pergunto", no lugar de "perguntava". Essa escolha de ponto de vista e, consequente, de capacidade de inferência sobre determinada situação passada cria uma versão superior de si próprio, um alter ego e está relacionada também à natureza da ilusão de realidade que se deseja produzir, e que Wayne Both (1980) designa como retórica da ficção8.

Seguindo na trama de Trevisan, somente no capítulo "Fuga de casa" é que se vê o movimento escapatório do ambiente insuportável que era seu próprio lar. Logo, apoiado pela mãe e totalmente desaprovado pelo pai, João ingressa no seminário endossando o estigma de "marica" que seu pai foi cultivando ao longo dos anos a respeito dele. Assim, ele se questiona: "O ataque à minha 'virilidade suspeita', desde pequeno, configuraria uma tentativa de meu pai sufocar em mim a sua própria infelicidade? Seria seu primogênito uma ameaça à ferida narcísica de José Trevisan?" (TREVISAN, 2017, p. 69).

Evidentemente, somente quando já dentro do seminário João se deu conta do erro que havia cometido: "[...] descobri tarde demais que eu caíra numa armadilha igualmente cheia de adversidades, ao me ver preso em novo contexto de opressão. Querendo escapar do ambiente massacrante da minha casa, deparei-me com um cotidiano controlado por regras severas" (TREVISAN, 2017, p. 70), restando, com isso, apenas lembranças de um período de duras regras, as quais o narrador-personagem pontua uma a uma de forma clara e objetiva.

8 Conjunto imponderável de oscilações que perfazem a técnica do autor que através de recursos estilísticos articula a obra para comunicar com seus leitores e impor seu universo ficcional. 
TREVISAN RESGATA TREVISAN EM PAI, PAl: o hibridismo no romance autobiográfico Edcleberton de Modesto • Ricardo Barberena

Para além da construção de um grande mapa de ausências afetivas, a obra também pode ser considerada como uma fonte de referências textuais romanescas, fílmicas, musicais e poéticas de diferentes autores, como o capítulo intitulado "Como desenhar um carneiro", fazendo referência ao livro infanto-juvenil O pequeno príncipe, de Antoine de Saint-Exupéry, o qual serviu de inspiração para um livro de própria autoria, chamado Em nome do desejo9. Além desses, também aparece no decorrer da narrativa referências como $O$ castelo do homem sem alma, Como era verde o meu vale, ou filmes, como A marca do Zorro, O homem que sabia demais, La Dolce Vita, etc, todos esses são responsáveis por ampliar o repertório cultural do narrador-personagem.

Essa interação entre vários textos de diferentes gêneros permite um entrelaçamento de suas lembranças com passagens descritas no enredo, revelando todo o seu processo de conhecimento agregado ao longo de sua vida, bem como uma inquietação perante a necessidade de se conhecer para construir-se na sua totalidade. Ao estudar esses aspectos de referencialidade, em seu artigo de 1968, intitulado "L'effet du réel", Barthes chamava a atenção para a quantidade de elementos presentes no texto, destacando, contudo, que eles não denotavam em nada o real, apenas conotavam o realismo, criando um efeito de real ao mesmo tempo em que reproduzem a ilusão realista ou referencial. Assim, segundo a modalidade de empréstimo a qual a ficção absorve, cabe ao leitor o trabalho de desdobramento e reconhecimento levado pelo narrador-personagem para o interior de sua autobiografia na premissa de construir uma percepção e significação para além dos limites ficcionais impostos pelo romance.

Ao averiguar os aspectos descritos acima a respeito do processo de referencialidade dentro da obra de Trevisan, convém ressaltar que, apesar de alguns avanços e regressos em sua história, o enredo segue uma lógica de linearidade que permite mostrar a perspectiva cronológica de sua vida. Assim, é possível inferir que

\footnotetext{
9 Lançado em 1983, o livro conta a história de amor entre os jovens seminaristas Abel e Tiquinho. Após trinta anos, um homem retorna ao seminário onde estudou, transformado em orfanato, e mergulha em suas recordações, principalmente na vivência de seu primeiro amor, do tempo em que era conhecido apenas por Tiquinho. Agora, é um homem amargo, quase alcóolatra, dividido entre o que se espera dele - casamento e sucesso na carreira - e sua verdadeira natureza.
} 
se trata de um bildungsroman, pois relata o processo de desenvolvimento moral, físico, psicológico ou mesmo político de João, desde sua infância até a maturidade. Logo, a associação entre os recursos de linguagem e seu caráter fragmentário possui características que lhe acrescentam a construção de diversos ângulos da memória.

A ilusão obtida através da ótica psicológica, traço marcante em Pai, pai (2017), revela digressões voluntárias como uma tentativa de escape dos fantasmas do seu inconsciente, criando um plano da memória paradoxal até atingir um plano teórico responsável pela busca de uma compreensão circunstancial e de funcionamento emocional de si e de como era tratado pelo pai. Assim, a adolescência proporcionou evoluções necessárias para o seu processo de autoafirmação, marcada por "constante depressão e instabilidade emocional" (TREVISAN, 2017, p. 125), mas também pelo abandono do seminário e da carreira sacerdotal, o qual "[...] significou abrir os braços para o mundo e me entregar a experiências insuspeitadas" (TREVISAN, 2017, p. 127). Desse modo, João deu "[...] adeus ao medo desse monstro que atormenta o desejo masculino de ser penetrado" (TREVISAN, 2017, p. 136) e se permitiu os primeiros encantos das paixões. Tal fato desencadeou sua primeira viagem à Europa e ao Norte da África, a qual deu início ao seu segundo exílio, uma vez que o primeiro já era vivido desde a infância na relação sentimental entre ele e José Trevisan.

À medida que a narrativa progride, é impossível não notar os mergulhos na psique do próprio personagem-narrador que, conhecedor das contribuições de Freud e de Jung no processo de entendimento do inconsciente humano, traz à luz breves discussões teóricas como tentativa de elaboração de si, como no capítulo "Freud e eu", mas também da análise do seu pai, assim, permitindo a João supor "[...] que o afastamento deliberado do universo paterno permitiu deflagrar o processo de libertação para ser quem sou, e isso implica automaticamente amar do jeito que me convém - como forma de superar o trauma. Veneno e antídoto, juntos" (TREVISAN, 2017, p. 142). 
Desse modo, é possível perceber um aprofundamento, quer seja no processo de "[...] assumir o exílio como forma de ser eu mesmo" (TREVISAN, 2017, p. 155), quer seja na capacidade e desenvoltura no manejo como ele se utiliza de sua biblioteca e do conhecimento pessoal para fazer da história dos teóricos uma referência comparativa à sua história para além da atualização de situações semelhantes, como uma espécie de movimento contínuo na memória humana. $O$ ir e vir entre a teoria e o texto literário possibilitam compreender a natureza e os mecanismos do hibridismo impostos através da intertextualidade presentificada no texto, ideia reforçada em toda a obra. Além disso, é possível verificar que o desfecho da história ganha contornos nítidos de um tom de perdão ao ver todo o desamparo e agonia da decadência pessoal de José Trevisan devido à sua dependência alcoólica. Essa conotação, o enredo novamente rompe com os limites de um romance tradicional e, no capítulo "Invocação ao perdão", assume as características de uma prece que demorou anos para acontecer na vida de João. Assim, ele diz:

[...] Pai, que me compeliu a procurar na misericórdia a artéria central do coração humano.

Pai, que me fez buscar o amor como desgraçado em busca da salvação.

Pai, a quem prometo perseguir o perdão como fio condutor da minha redenção.

Pai, não há perdão que não seja mútuo.

Peço teu perdão, meu pai (TREVISAN, 2017, p. 233).

A partir da passagem acima, é possível inferir o quanto o desamparo paterno trouxe sequelas emocionais na vida de João, mas também permitiu a compreensão de uma busca de si. Neste caso, “[...] o perdão articula, promove, impõe uma perfeita revolução no interior da alma" (TREVISAN, 2017, p. 235). No entanto, é crível averiguar que, mesmo diante da face do perdão, os capítulos posteriores seguem com uma série de teorizações e discussões sobre o 
que poderia ter provocado tal comportamento de José para com ele. O amargor de uma vida à margem do carinho e do afeto do pai permitiu a João o encontro de um pai de si mesmo, assim, a real busca de um sentido verdadeiro tatuou cicatrizes na alma que evidenciam o ápice da vida humana. Desse modo, ele conclui dizendo que: "Meu pai existiu. Me deu um espermatozoide. Meu pai me deu esse começo. Digamos que me deixou marcas para não esquecer. [...] Meu pai me deu um espermatozoide, e assim eu gerei um pai" (TREVISAN, 2017, p. 253).

Nesse cruzamento de fronteiras entre o tom ficcional e o tom ensaístico ou mesmo teórico, João Silvério Trevisan precisou se concentrar naquilo que o romance autobiográfico por si só não seria capaz de dar conta. Logo, foi forçado a romper com os aspectos mais comuns desse gênero e entregar-se à representação da essência através de suas teses e antíteses distorcidas, as quais, dessa forma, provocaram densa e cerradamente a compreensão e o perdão de uma época de sua vida, como uma espécie de mergulho hermético que impedia o fechamento de um ciclo e início de outro. Assim, o narrador-personagem mistura efeitos da hibridização ao da fragmentação como uma tentativa de traduzir este último como uma quebra do eu, ou seja, a impossibilidade de encontrar-se como uma unidade harmoniosa.

\section{Considerações finais}

Para além da autobiografia relatada, a qual constitui um inventário mnemônico da relação conflituosa entre João e José, ao analisar a estrutura da obra, corpus deste trabalho, é pertinente salientar que a descrição dos eventos narrados, alicerçada ao hibridismo, resulta em um levantamento de acervo pessoal das leituras e produções próprias de João ao longo da vida. Assim, a escrita de si atua em três níveis necessários: a memória trazida pelo texto, a memória do autor e a memória do leitor. Ao observar esses aspectos, percebe-se que a obra em apreço pode servir 
como fonte de estudos no campo da crítica genética do autor, uma vez que Pai, pai (2017) perfaz a categoria do gênero literário acima.

Conforme foi apontado nos objetivos deste trabalho, a intertextualidade, como desdobramento paradoxal nos modos de referenciação literária da obra de João Silvério Trevisan, rompe com operações e transforma o ato de narrar em uma integração e montagem desfigurada, mas, ao mesmo tempo, coloca-a em parâmetros singulares perante a configuração do romance autobiográfico contemporâneo. A perspectiva dada ao enredo pelo autor marca grandes processos de reflexões sobre si e sua escrita, assumindo características de um romance metaficcional. Assim, o estatuto da transgressão imposto à obra percorre pontos que propiciam a ambiguidade e a indeterminação do mundo narrado. Ao transgredir o enredo inserindo inúmeras referências, o narrador-personagem consegue se colocar no universo da literatura, considerando-a como contextualização e entendimento de sua vida.

Por outro lado, é sabido que, "se o romance clássico narrou o mundo do homem, se o romance do século passado se perguntou gnoseologicamente o como do mundo do homem, esta corrente que nos envolve hoje procura a resposta para o porquê e para o para quê do mundo do homem" (CORTÁZAR, 1974, p. 79). A verdade secreta substituiu a necessidade fantasiosa e abriu espaço para uma nova maneira de narrar, diferente daquelas produzidas nas décadas anteriores. Por mais que se trate de uma autobiografia, qualquer que seja sua sinceridade, nível de verdade e/ou desejo de veracidade, vai agregar a ficção como elemento indispensável. Assim, a fragmentação elimina a pretensão do narrador em dar conta da totalidade de sua história, enquanto o hibridismo, por sua vez, marca o gênero em análise por sua indeterminação.

Mediante o desenvolvimento deste trabalho, ao analisar como o hibridismo se comporta dentro do enredo da obra, foi possível observar como o estilo próprio do escritor paulista, João Silvério Trevisan, trouxe novas possibilidades para as narrativas autobiográficas brasileiras. Por fim, as considerações precedentes permitiram verificar que o hibridismo e a fragmentação atuam como 
TREVISAN RESGATA TREVISAN EM PAI, PAl: o hibridismo no romance autobiográfico Edcleberton de Modesto • Ricardo Barberena

princípios que permitem novas características para a configuração do romance autobiográfico.

\section{Referências}

BARTHES, Roland. O rumor da língua. Tradução de Mario Laranjeira. $3^{a}$ ed. São Paulo. Editora WMF Martins Fontes, 2012.

BOOTH, Wayne. Retórica da ficção. Tradução de Maria Tereza H. Guerreiro. Lisboa: Arcádia, 1980.

CORTÁZAR, Julio. Valise de Cronópio. Tradução de Davi Arriguci Jr. e João Alexandre Barbosa. São Paulo: Perspectiva, 1974.

DOUBROVSKY, Serge. "O último eu”. In: NORONHA, Jovita Maria Gerheim (org.). Ensaios sobre a autoficção. Belo Horizonte: Editora UFMG, 2014. p. 45-63.

GENETTE, Gérard. Figuras III. Tradução de Ana Alencar. São Paulo: Liberdade, 2017.

LEJEUNE, Philippe. O pacto autobiográfico. Tradução de Jovita Maria Gerheim Noronha e Maria Inês Coimbra Guedes. Belo Horizonte: UFMG, 2008.

REUTER, Yves. A análise da narrativa: o texto, a ficção e a narração. Tradução de Mario Pontes. 4ª ed. Rio de Janeiro. DIFEL, 2004.

RICHARDSON, Brian. Unnatural Voices: extreme narration in modern and contemporary fiction. Trad. de Paulo Ricardo Kralik Angelini. Columbus: The Ohio State University Press, 2006.

SAMOYAULT, Tiphaine. A intertextualidade. Tradução de Sandra Nitrini. São Paulo: Aderaldo \& Rothschild, 2008.

SÜSSEKIND, Flora. Tal Brasil, qual romance? Rio de Janeiro: Achiamé, 1984. TREVISAN, João Silvério. Pai, pai. 1ª ed. Rio de Janeiro: Alfaguara. 2017. WATT, Ian. A ascensão do romance: estudos sobre Defoe, Richardson e Fielding. Tradução de Hildegard Feist. São Paulo: Companhia das Letras, 2010. 